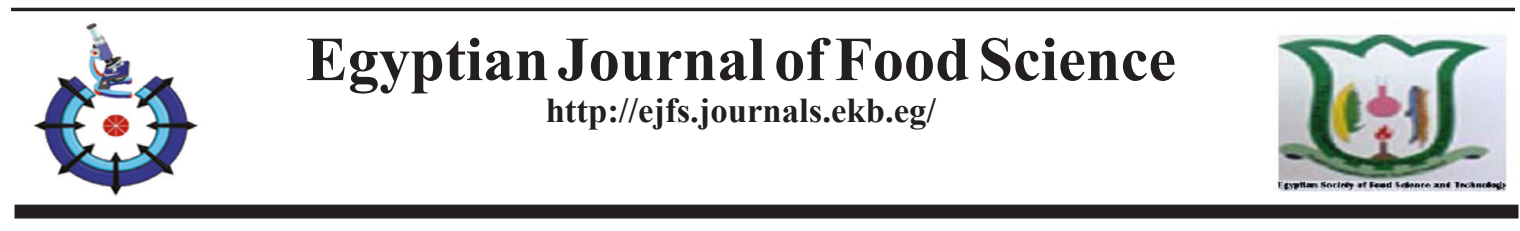

\title{
Influence of Some Probiotic Bacteria on The Improvement of Taizzy Soft Cheese Quality
}

\author{
Mohamed B. El-Alfy ${ }^{1}$, Mohamed E. Shenana ${ }^{1}$, Nabil S. M. Al-Dubai ${ }^{2}$, and \\ Elsayed A. Ismail ${ }^{1 *}$ \\ ${ }^{1}$ Dairy Sci. Dept., Fac. Agric., Moshtohor, Benha University, Egypt \\ ${ }^{2}$ Food Sci. and Technology Dept., Fac. Agric., Ibb Univ., Ibb Yemen
}

\begin{abstract}
$\mathbf{T}$ HIS study aimed to improve the quality properties and sanitary production conditions of Taizzy soft cheese by using some of new isolate of Lactobacillus rhamnosus Iso 7 and $L$. plantarum ATCC14917. Incorporate the selected probiotic organisms into Taizzy soft cheeses and the performance of these organisms in terms of their survival during cheese-making and ripening, as well as the influence of probiotic organisms on product quality as assessed by the composition of the cheeses. The proteolytic pattern, amino acid profile and the sensory evaluation of the cheese were investigated. The results showed that Taizzy soft cheeses made with probiotic bacteria could be an efficient vehicle for different probiotic bacteria until they reach the consumer. Sensory evaluation indicated that probiotic Taizzy soft cheeses made with Lactobacillus rhamnosus Iso7 strain achieved significant high scores of body \& textures when fresh and during storage periods. Taizzy cheese with different probiotic strains had improved appearance, colour and overall acceptability.
\end{abstract}

Keywords: Taizzy cheese, Probiotic, Cheese slurry, Ripening, Proteolysis.

\section{Introduction}

Cheese is recognized to be of abundant nutritional value for human consumption. Protein in cheese has a high biological value and cheese contains all essential amino and fatty acids. As well as it is a good source of minerals and vitamins (Abd-Elaty, 1994 and Dalloul, 2000). Many kinds of Taizzy soft cheese are in Yemeni market such as fresh, soft, dry, half dry, smoked, and non-smoked, with and without salt. The rennet used for coagulation this type of cheese is obtained from stomach of suckling goats. Unfortunately, there are not enough studies published on this type of cheese (El-Shamery, 2007). Taizzy cheeses are traditional cheeses made of raw goat and cow milk. It may be sold as fresh cheese, which is a soft cheese with a high moisture content and limited shelf life of 3-7 Days. Most of Taizzy soft cheese is a semi hard cheese in small smoked wheels with thin brown smoked rind. The shelf life varies depending on the salt content. The shelf life of low salt cheese (sweet) is 7-10 days, where it is extended to 2-4 weeks for salted cheese. The average composition for smoked Taizzy soft cheese is $47.17 \%$ moisture, $21.22 \%$ fat, $13,92 \%$ protein and $5.22 \%$ salt. The Average composition of the Taizzy cheese is $58.02 \%$ moisture, $19.75 \%$ fat, $15.27 \%$ protein and $3.21 \%$ salt (Abdulmalek \& Abdulaziz, 2011).

The objective of this study was to investigate the effect of some Probiotic bacteria on the quality improvement of Taizzy soft cheese and produce probiotic Taizzy soft cheese from mixed cow's and buffalo's milk.

\section{Materials and Methods}

Materials

Fresh mixed Cow's and Buffalo's milk (1:1) were obtained from the herds of Moshtohor, Fac.,

"Corresponding author : E-mail: e.ismail@fagr.bu.edu.eg, sayed1973@yahoo.com

Received:21/6/2020; accepted:9/8/2020

DOI: $10.21608 /$ EJFS.2020.33440.1062

(C)2020 National Information and Documentation Centre (NIDOC) 
of Agric., Benha Univ. Freeze dried conventional yoghurt starter culture (FD-DVS YC-X11-YoFlex) containing Lactobacillus delbrueckii ssp. bulgaricus and Streptococcus thermophilus (1:1) was obtained from Chr. Hansen's Laboratories, Copenhagen, Denmark and purchased from MIFAD Company, Egypt. Freeze dried isolate of Lactobacillus rhamnosus Iso7 was isolated from infant and genetically identified (Ismail, 2007) at Institute of Microbiology, Federal Research Center for Nutrition and Food, Kiel, Germany. Lactobacillus plantarum ATCC 14917 was obtained from National Research Center, Giza, Egypt. Rennet was obtained from the Dairy Sci., Dept., Fac., of Agric., Moshtohor. A commercial pure fine grade table salt was obtained from ElNaser Company, Egypt. Potassium sorbate was obtained from El-Gomhoria Co., Cairo, Egypt.

\section{Methods}

\section{Preparation of Slurries and fresh curd}

Fresh curd and slurries were prepared according to Abd-El-Hamid et al. (1991) Hofi et al. (1991). The first slurry was used as a (Control) containing yoghurt starter culture (Streptococcus thermophilus and Lactobacillus delbrueckii subsp. bulgaricus). Second slurry contained yoghurt starter and Lactobacillus rhamnosus Iso7 (1:1). Third slurry contained yoghurt starter and Lactobacillus plantarum ATCC 14917 (1:1). All the treatments were inoculated $1 \%$ and incubated at $40{ }^{\circ} \mathrm{C}$ for 7 days.

\section{Preparation of Probiotic Taizzy soft cheese}

The mixed milk was heated up to $76^{\circ} \mathrm{C}$ in water bath and cooled to $\sim 40{ }^{\circ} \mathrm{C}, 4 \%$ salt was added and dissolved through cheese cloth. Previously prepared slurry was added to the milk at a rate of $1 \%$. According to the cheese treatments the inculcated milk was left for $1 \& 2 \mathrm{hr}$ before renneting. Required amount of standard rennet solution was added and kept at $40^{\circ} \mathrm{C}$ until complete coagulation. The cheese curd was filled in sealed moulds about $1 / 2 \mathrm{Kg}$ capacity and was left overnight to drain whey by the gravity. On the next day, the moulds turned upside down and left up to 4 hours. The moulds then taken off and the resultant cheese stored refrigerated $\left(\sim 5^{\circ} \mathrm{C}\right)$ with sterilized $4 \%$ brine solution in a plastic container. Cheese samples were analyzed when fresh, 7, 14, 21 and 28 days, respectively for chemical, microbiological, rheological, and organoleptic properties.

\section{Chemical analysis}

Total Solids, titratable acidity, $\mathrm{pH}$ values, fat and salt were determined according to the methodology mentioned in IDF (1987), AOAC (2012), IDF (1996) and BSI (1989), respectively. Total nitrogen (T.N) and soluble nitrogen (S.N) were determined according to AOAC (2012). Determination of free amino acids of cheese was determined as described by AOAC (2016).

\section{Microbiological examination}

The total bacterial counts of cheese were determined according to the American Public Health Association (APHA, 2004). Lactobacilli counts were performed on MRS agar and incubated anaerobically at $37^{\circ} \mathrm{C}$. Yeast and moulds counts were enumerated as described by APHA (2004). Coliform bacteria group was tested as suggested by the BSI (1993).

\section{Sensory evaluation}

The organoleptic evaluations were done by 10 experienced Food Scientists of Dairy Sci., Dept., Fac., of Agric., Moshtohor, Benha Univ., Egypt. Samples of cheese were sensory evaluated according to the scheme described by IDF (1997).

\section{Statistical analysis}

Statistical analysis of the obtained data was performed according to the user's guide given by SAS (1990).

\section{Results and discussion}

Gross chemical composition of probiotic Taizzy soft cheese during storage

Table 1 represents the chemical composition of probiotic Taizzy soft cheese when fresh and during storage. Total solids content is one of the most commonly measurable parameter of food materials for microbial food qualities, legal, labeling requirements, and shelf life. The T.S. content of probiotic Taizzy soft cheese without and with different probiotic strains were gradually increased along storage period till 28 days. The gradual increase of T.S. could be attributed to the decrease of moisture content during storage due to shrinkage of the curd because of acid development which helps to expel the whey from the curd. The results agree with those of El-Alfy et al. (2010). Similar results also were obtained by Abd EL-Salam et al. (2011) as they attributed the loss in moisture content and the increase in TS during storage to the developed acidity leading to shrinkage of cheese matrix and partial losses of cheese serum in brine. Fat and fat in dry matter (F/DM) content of probiotic Taizzy soft cheese with different probiotic strains were significantly

Egypt. J. Food Sci. 48, No.2 (2020) 
TABLE 1. Gross chemical composition g/100g-1 of probiotic Taizzy cheese during storage at 50C period up to 28 days

\begin{tabular}{|c|c|c|c|c|c|c|c|}
\hline \multirow{2}{*}{$\begin{array}{c}\text { Storage } \\
\text { period } \\
\text { (days) }\end{array}$} & \multicolumn{7}{|c|}{ Treatments } \\
\hline & C1 & $\mathrm{C2}$ & T1 & $\mathbf{T 2}$ & T3 & T4 & MSE \\
\hline \multicolumn{8}{|c|}{ T.S\% } \\
\hline $\mathbf{0}$ & $32.21^{\mathrm{a}}$ & $32.22^{\mathrm{a}}$ & $32.40^{\mathrm{a}}$ & $32.58^{\mathrm{a}}$ & $32.63^{\mathrm{a}}$ & $32.87^{\mathrm{a}}$ & 2.53 \\
\hline 7 & $34.33^{\mathrm{a}}$ & $34.44^{\mathrm{a}}$ & $34.59^{\mathrm{a}}$ & $34.82^{\mathrm{a}}$ & $34.97^{\mathrm{a}}$ & $35.03^{\mathrm{a}}$ & 2.53 \\
\hline 14 & $36.51^{\mathrm{a}}$ & $36.67^{\mathrm{a}}$ & $36.71^{\mathrm{a}}$ & $36.89^{\mathrm{a}}$ & $36.99^{\mathrm{a}}$ & $37.11^{\mathrm{a}}$ & 2.53 \\
\hline 21 & $39.01^{\mathrm{a}}$ & $39.07^{\mathrm{a}}$ & $39.12^{\mathrm{a}}$ & $39.22^{\mathrm{a}}$ & $39.37^{\mathrm{a}}$ & $39.58^{\mathrm{a}}$ & 2.69 \\
\hline 28 & $42.01^{\mathrm{a}}$ & $43.05^{\mathrm{a}}$ & $43.10^{\mathrm{a}}$ & $43.15^{\mathrm{a}}$ & $43.21^{\mathrm{a}}$ & $43.23^{\mathrm{a}}$ & 2.72 \\
\hline \multicolumn{8}{|c|}{ Fat $\%$} \\
\hline $\mathbf{0}$ & $15.05^{\mathrm{a}}$ & $14.80^{\mathrm{a}}$ & $14.95^{\mathrm{a}}$ & $15.02^{\mathrm{a}}$ & $14.99^{\mathrm{a}}$ & $15.21^{\mathrm{a}}$ & 1.52 \\
\hline 7 & $16.48^{\mathrm{a}}$ & $16.48^{\mathrm{a}}$ & $16.53^{\mathrm{a}}$ & $16.80^{\mathrm{a}}$ & $16.72^{\mathrm{a}}$ & $17.56^{\mathrm{a}}$ & 1.56 \\
\hline 14 & $18.41^{\mathrm{a}}$ & $18.44^{\mathrm{a}}$ & $18.57^{\mathrm{a}}$ & $18.87^{\mathrm{a}}$ & $18.89^{\mathrm{a}}$ & 18.83 & 1.56 \\
\hline 21 & $20.20^{\mathrm{a}}$ & $20.18^{\mathrm{a}}$ & $20.11^{\mathrm{a}}$ & $20.20^{\mathrm{a}}$ & $20.53^{\mathrm{a}}$ & $20.63^{\mathrm{a}}$ & 1.85 \\
\hline 28 & $24.37^{\mathrm{a}}$ & $24.60^{\mathrm{a}}$ & $24.56^{\mathrm{a}}$ & $24.49^{\mathrm{a}}$ & $24.42^{\mathrm{a}}$ & $24.33^{\mathrm{a}}$ & 2.05 \\
\hline \multicolumn{8}{|c|}{ Fat/DM\% } \\
\hline $\mathbf{0}$ & $46.72^{\mathrm{a}}$ & $45.93^{\mathrm{a}}$ & $46.14^{\mathrm{a}}$ & $46.10^{\mathrm{a}}$ & $45.94^{\mathrm{a}}$ & $46.27^{\mathrm{a}}$ & 3.42 \\
\hline 7 & $48.00^{\mathrm{a}}$ & $47.85^{\mathrm{a}}$ & $47.88^{\mathrm{a}}$ & $48.25^{\mathrm{a}}$ & $47.81^{\mathrm{a}}$ & $50.13^{\mathrm{a}}$ & 3.42 \\
\hline 14 & $50.64^{\mathrm{a}}$ & $50.29^{\mathrm{a}}$ & $50.59^{a}$ & $51.15^{\mathrm{a}}$ & $51.07^{\mathrm{a}}$ & $50.74^{\mathrm{a}}$ & 3.42 \\
\hline 21 & $51.83^{\mathrm{a}}$ & $51.69^{\mathrm{a}}$ & $51.41^{\mathrm{a}}$ & $51.50^{\mathrm{a}}$ & $52.15^{\mathrm{a}}$ & $52.12^{\mathrm{a}}$ & 3.58 \\
\hline 28 & $58.00^{\mathrm{a}}$ & $57.15^{\mathrm{a}}$ & $56.98^{\mathrm{a}}$ & $56.76^{\mathrm{a}}$ & $56.51^{\mathrm{a}}$ & $56.28^{\mathrm{a}}$ & 3.58 \\
\hline \multicolumn{8}{|c|}{ Protein \% } \\
\hline $\mathbf{0}$ & $9.50^{\mathrm{a}}$ & $9.52^{\mathrm{a}}$ & $9.69^{\mathrm{a}}$ & $9.73^{\mathrm{a}}$ & $9.80^{\mathrm{a}}$ & $9.87^{\mathrm{a}}$ & 0.56 \\
\hline 7 & $10.04^{\mathrm{a}}$ & $10.06^{\mathrm{a}}$ & $10.11^{\mathrm{a}}$ & $10.16^{\mathrm{a}}$ & $10.23^{\mathrm{a}}$ & $10.29^{\mathrm{a}}$ & 0.62 \\
\hline 14 & $10.39^{a}$ & $10.52^{\mathrm{a}}$ & $10.72^{\mathrm{a}}$ & $10.83^{\mathrm{a}}$ & $10.91^{\mathrm{a}}$ & $11.03^{\mathrm{a}}$ & 0.62 \\
\hline 21 & $11.75^{\mathrm{a}}$ & $11.88^{\mathrm{a}}$ & $12.01^{\mathrm{a}}$ & $12.11^{\mathrm{a}}$ & $12.24^{\mathrm{a}}$ & $12.31^{\mathrm{a}}$ & 1.23 \\
\hline 28 & $11.23^{\mathrm{a}}$ & $12.05^{\mathrm{a}}$ & $12.15^{\mathrm{a}}$ & $12.27^{\mathrm{a}}$ & $12.37^{\mathrm{a}}$ & $12.42^{\mathrm{a}}$ & 1.29 \\
\hline \multicolumn{8}{|c|}{ Protein/DM\% } \\
\hline $\mathbf{0}$ & $29.49^{a}$ & $29.54^{\mathrm{a}}$ & $29.91^{\mathrm{a}}$ & $29.58^{\mathrm{a}}$ & $30.04^{\mathrm{a}}$ & $29.50^{\mathrm{a}}$ & 1.32 \\
\hline 7 & $29.17^{\mathrm{a}}$ & $29.21^{\mathrm{a}}$ & $29.28^{\mathrm{a}}$ & $29.17^{\mathrm{a}}$ & $29.29^{a}$ & $29.37^{\mathrm{a}}$ & 1.32 \\
\hline 14 & $28.03^{\mathrm{a}}$ & $28.70^{\mathrm{a}}$ & $29.20^{\mathrm{a}}$ & $29.33^{\mathrm{a}}$ & $29.51^{\mathrm{a}}$ & $29.72^{\mathrm{a}}$ & 1.32 \\
\hline 21 & $30.13^{\mathrm{a}}$ & $30.40^{\mathrm{a}}$ & $30.70^{\mathrm{a}}$ & $30.87^{\mathrm{a}}$ & $31.09^{\mathrm{a}}$ & $31.11^{\mathrm{a}}$ & 1.35 \\
\hline 28 & $26.73^{b}$ & $26.83^{\mathrm{ab}}$ & $28.20^{\mathrm{a}}$ & $28.44^{\mathrm{a}}$ & $28.62^{\mathrm{a}}$ & $28.74^{\mathrm{a}}$ & 1.63 \\
\hline \multicolumn{8}{|c|}{ Salt\% } \\
\hline $\mathbf{0}$ & $4.01^{\mathrm{a}}$ & $4.25^{\mathrm{a}}$ & $4.20^{\mathrm{a}}$ & $4.30^{\mathrm{a}}$ & $4.33^{\mathrm{a}}$ & $4.30^{\mathrm{a}}$ & 0.61 \\
\hline 7 & $4.29^{\mathrm{a}}$ & $4.45^{\mathrm{a}}$ & $4.57^{\mathrm{a}}$ & $4.66^{\mathrm{a}}$ & $4.76^{\mathrm{a}}$ & $5.00^{\mathrm{a}}$ & 0.61 \\
\hline 14 & $4.77^{\mathrm{a}}$ & $4.83^{\mathrm{a}}$ & $4.92^{\mathrm{a}}$ & $4.95^{\mathrm{a}}$ & $5.08^{\mathrm{a}}$ & $5.12^{\mathrm{a}}$ & 0.61 \\
\hline 21 & $5.06^{\mathrm{a}}$ & $5.10^{\mathrm{a}}$ & $5.15^{\mathrm{a}}$ & $5.17^{\mathrm{a}}$ & $5.19^{\mathrm{a}}$ & $5.23^{\mathrm{a}}$ & 0.61 \\
\hline 28 & $5.25^{\mathrm{a}}$ & $5.26^{\mathrm{a}}$ & $5.29^{\mathrm{a}}$ & $5.32^{\mathrm{a}}$ & $5.35^{\mathrm{a}}$ & $5.41^{\mathrm{a}}$ & 0.61 \\
\hline \multicolumn{8}{|c|}{ Salt/Moisture\% } \\
\hline $\mathbf{0}$ & $5.91^{\mathrm{a}}$ & $6.27^{\mathrm{a}}$ & $6.21^{\mathrm{a}}$ & $6.38^{\mathrm{a}}$ & $6.42^{\mathrm{a}}$ & $6.37^{\mathrm{a}}$ & 0.97 \\
\hline 7 & $6.54^{\mathrm{a}}$ & $6.79^{\mathrm{a}}$ & $6.98^{\mathrm{a}}$ & $7.14^{\mathrm{a}}$ & $7.32^{\mathrm{a}}$ & $7.70^{\mathrm{a}}$ & 0.97 \\
\hline 14 & $7.52^{\mathrm{a}}$ & $7.63^{\mathrm{a}}$ & $7.79^{\mathrm{a}}$ & $7.84^{\mathrm{a}}$ & $8.06^{\mathrm{a}}$ & $8.14^{\mathrm{a}}$ & 0.97 \\
\hline 21 & $8.30^{\mathrm{a}}$ & $8.38^{\mathrm{a}}$ & $8.46^{\mathrm{a}}$ & $8.51^{\mathrm{a}}$ & $8.57^{\mathrm{a}}$ & $8.66^{\mathrm{a}}$ & 0.97 \\
\hline 28 & $9.05^{\mathrm{a}}$ & $9.23^{\mathrm{a}}$ & $9.29^{\mathrm{a}}$ & $9.37^{\mathrm{a}}$ & $9.43^{\mathrm{a}}$ & $9.53^{\mathrm{a}}$ & 0.97 \\
\hline
\end{tabular}

(C1) Control without slurry (One hour), (C2) Control without slurry (two hours), (T1) L. rhamnosus Iso 7 (One hour), (T2) L. rhamnosus Iso7 (two hours), (T3) L. plantarum ATCC 14917 (One hour),(T4) L. plantarum ATCC 14917 (two hours). a,b,c Means with different superscript in the same row are significantly different at (Pप0.05). 
increased prior to advancement of cold storage up to 28 days, due to the slight increase in T.S. or moisture losses at storage conditions. The results are in accordance with those recorded by Effat et al. (2012). Similar trends of data were obtained by EL-Alfy et al. (2010) and Abd EL-salam et al. (2011), They attributed such increase in fat due to storage and the loss of moisture content or increase in T.S. of cheese and losses of the soluble constituents in the cheese brine. The protein and P/DM contents of fresh probiotic Taizzy soft cheese with different probiotic strains were in a narrow ranging from 9.50 to 9.87 for $\mathrm{C} 1$ and $\mathrm{T} 4$, respectively. The protein content of all treatments significantly increased because of extending the refrigeration storage up to 28 days of storage. This increase of protein ratios is related to partial loss of moisture content because of development of acidity in all probiotic Taizzy soft cheese treatments through cold storage period. Similar trends were found by Triana et al. (2016).

The salt content and salt-in-moisture phase of Taizzy soft cheese made with different types of probiotic bacteria during storage at $5^{\circ} \mathrm{C}$ up to 28 days ranged in narrow values for all cheese treatments ranged from 4.01 to $4.33 \%$ for $\mathrm{C} 1$ and $\mathrm{T} 3$, respectively. There were slightly increase in salt content during storage periods (28 days). This may be due to loss in moisture content of nontraditional cheese. Same observations were found by (Algarni, 2016). The moisture retention in the cheese was affected by the acidity development which also affected by the ratio of starter culture used. Statistical analysis for the obtained data indicated that salt content and salt-in-moisture ratio were significant affected $(\mathrm{p} 0.05<)$ by the interval storage periods.

The statistical analysis of the gross chemical composition of probiotic Taizzy cheese during storage, cleared that there were highly significant differences between the interval storage periods. On the other hand, there were non-significant differences between different treatments for all the tested parameters.

\section{Titratable acidity and $\mathrm{pH}$ values}

Titratable acidity is a very important factor, which affects the shelf life and acceptability of fermented dairy products and cheeses. The titratable acidity values of all fresh probiotic Taizzy soft cheese with different probiotic strains ranged from 0.23 to $0.30 \%$ and significantly increased during storage reaching $1.30 \%$ to 1.53 $\%$ at 28 days of cold storage period (Fig. 1a). This increase in the level of the acidity is due to the activity and growth of lactic acid bacteria and the presence of different probiotic strains.

All the produced probiotic Taizzy soft cheese with different probiotic strains treatments exhibited significantly higher acidity values than control (C1). Meanwhile, treatments $\mathrm{C} 2$ and $\mathrm{T} 1$ gained the lowest values of acidity, whereas treatment $\mathrm{T}_{4}$ gained the highest values along storage period. These results agree with those of Gomes et al. (2011). The pH values (Fig. 1b) took an opposite trend of acidity, as it decreased throughout the storage period but did not fall below $\mathrm{pH}$ 4.0, which is generally considered detrimental to the survival of probiotic bacteria, to reach the lowest levels at end of storage and ranged from 3.04 to 3.66. Similar tendencies for $\mathrm{pH}$ values were observed by Gomes et al. (2011). Moreover, the significant decrease of $\mathrm{pH}$ values for each treatment during storage period could be due accumulation of lactic and other organic acids which produced by lactic acid bacteria and other living probiotic microorganisms during storage or the metabolic activity of probiotic strains (Astawan et al., 2012, Gamage et al., 2016). Statistical analysis of the changes in acidity and $\mathrm{pH}$ values indicated that, there were significant differences either between the treatments and the controls also there were significant differences between the treatments each to other. During the storage periods there were also significant differences between the intervals' storage periods for all the treatments. On the other hand, the $\mathrm{pH}$ values statistical analysis cleared that there were no significant differences either between the treatments or among storage periods.

\section{Ripening indices of Taizzy soft cheese with different probiotic strains}

The ripening indices of Taizzy soft cheese with different probiotic strains when fresh and during storage period at $\sim 5^{\circ} \mathrm{C}$ for 28 days is presented in Table 2.

The SN contents (\%) significantly increased in all probiotic treatments compared with control $\left(\mathrm{C}_{1}\right)$ when fresh and by extending the refrigeration storage period up to 28 days. The treatment (T4) and treatment (T3) had the highest SN contents $(0.78 \%)$ and $(0.75 \%)$, consecutively. On the other hand, the control $(\mathrm{C} 1)$ recorded the lowest SN content $(0.48 \%)$. This increase of SN values could be due to the protein breakdown of cheese by milk enzymes, rennet, and / or other microbial activities. These results agree with those reported

Egypt. J. Food Sci. 48, No.2 (2020) 


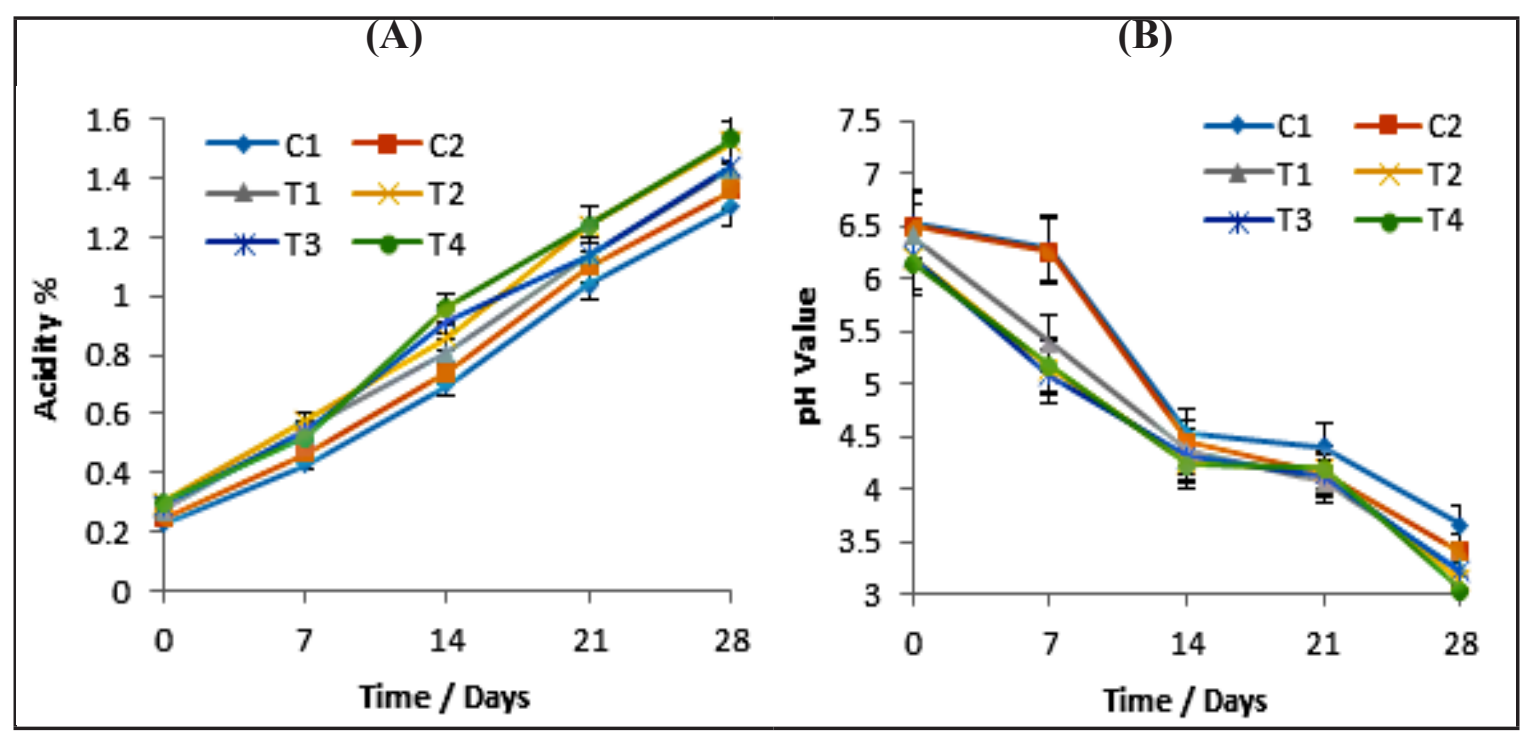

Fig.1. Changes in acidity (A) and pH (B)\% of Taizzy soft cheese made with different types of probiotic bacteria during storage at $5^{\circ} \mathrm{C}$ up to 28 days. (C1) Control without slurry (One hour), (C2) Control without slurry (two hours), (T1) L. rhamnosus Iso 7 (One hour), (T2) L. rhamnosus Iso 7 (two hours), (T3) L. plantarum ATCC 14917 (One hour), (T4) L. plantarum ATCC 14917 (two hours)

by El-Alfy et al. (2010) and Effat et al. (2012). Taizzy soft cheese made with different probiotic strains had higher values of soluble nitrogen / Total nitrogen (SN/TN) compared with the control when fresh and along the storage period. However, the soluble nitrogen of both control and treated cheese increased gradually during storage with different rates according to the added probiotic strains. The SN/TN reflects ripening and more proteolysis of the produced cheeses. On the other hand, the highest SN/TN values on the respect suggesting adding probiotic strains was more effective in cheese storage and ripening. Such impact can be attributed to the presence of higher level of proteases remained in cheese during ripening (Mehanna et al., 2009). The different strains of probiotic bacteria produced a different impact on secondary proteolysis of probiotic Taizzy cheeses. L. plantarum and $L$. rhamnosus produced the higher effect with an increase in the levels of free amino acids and the fraction of SN. The differences of the proteolytic activity of probiotic bacteria can be attributed to the heterogeneity in their peptidolytic potential, and actual activity of the enzymes in the cheese matrix, which are largely strain-dependent (Ong et al., 2007, Albenzio et al., 2013). Statistical analysis of soluble nitrogen and soluble nitrogen /total nitrogen (SN/TN) indicated that there were significant differences between all the treatments and the controls. Also, there were significant differences between the intervals' storage periods due to the actions of different probiotic strains. The probiotic Taizzy soft cheese made with different types of probiotic bacteria when fresh and during storage, showed higher Shilovich values than the control cheese. This could be attributed to the production of proteases by the probiotic added to the experimental cheese, and the effect of proteases on protein hydrolysis of the treated cheese into many kinds of peptides and amino acids, therefore, there was a significant difference and increase in Shilovich ripening index (SRI) along the ripening period, and hence it was correlated to the percentage of probiotic. Similar results were reported by EL-Sayed et al. (1993), and Mehanna et al. (2009).

Formal Ripening Index of fresh cheese gradually increased throughout storage for all the cheese treatments. The obtained results supported the concept that the addition of probiotics highly affected the hydrolysis of protein (El-Sayed et al., 1993). Statistical analysis cleared that there were significant differences between the intervals' storage periods. However, there were non- significant differences between different treatments. 
The soluble tyrosine content of control and experimental cheese increased throughout the storage period. This can be attributed to the action of proteolytic enzymes of the probiotic strains, which affect the protein degradation resulting in releasing more tyrosine which is considered as a ripening index for cheese ripening. These results are in accordance with those given by EL-Shafei (2015). The soluble tryptophan content of control and probiotic cheeses were increased as storage (ripening) progressed up to 28 days. Moreover, the increase of soluble tryptophan content of the experimental cheese was in different rates. This reflects the effect of proteolytic enzymes of slurry on protein degradation and hence producing more tryptophan content which is also used as a ripening index for cheese. The obtained results agree with those obtained by Ali (2010) who reported that the increase of soluble tryptophan content either in control or the treatments were clear and highly significant different during the storage period of cheeses. The results also are in accordance with that obtained by Abd El-Salam et al. (1993) and EL-Shafei (2015). According to the statistical analysis of tyrosine and tryptophan data, there was a significant difference between the control cheese and the different treatments. At the same time there were significant differences among different treatments each to other. The Total volatile fatty acids (TVFA) consider being the most volatile organic compounds in dairy and dairy products are associated with odor and taste. The volatile compounds of cheeses play an important role for the consumer acceptance. Fatty acids usually released by the actions of either lipase from different sources during lipolysis or action of microorganisms. The TVFA of fresh produced probiotic Taizzy soft cheese with different probiotic strains were significantly increased for all treatments as storage period progressed up to 28 days reaching the maximum values. This increase may be due to the ability of starter culture especially proteolytic and lipolytic bacteria to convert lactic acid, citrate, fat, and protein into volatile compounds. These findings are consistent with those reported by Wijesundera et al. (1997) who reported that the free fatty acids concentrations in cheese slurries varied depending on the starter strain used. Treatment $\left(\mathrm{T}_{4}\right)$ followed by treatment $\mathrm{T}_{3}$ recorded the maximum values of TVFA while the control $\left(\mathrm{C}_{1}\right)$ had the minimum values throughout the intervals of storage periods. This could be explained on the bases that slurry contained fatty acids (Abd-EL-Hamid et al., 1991).

Egypt. J. Food Sci. 48, No.2 (2020)
The rate of lipolysis in probiotic soft Taizzy cheese treatments was higher due to the presence of lipolytic enzymes normally produced by probiotic slurry strains. Statistical analysis of TVFA data cleared that there were high significant differences between all the treatments and controls also, there were significant differences between intervals storage periods up to the end of the storage.

\section{Proteolysis assessment and free amino acids}

Proteolysis is a major factor involved in the cheese ripening and affects either the flavour or texture of the product. Proteolysis is essential to the development of flavour and texture in all cheeses. Proteolytic enzymes are derived from three sources: A) rennet or other coagulant, B) plasmin and C) both starter and non-starter microorganisms. Degree of ripening for the produced probiotic soft Taizzy cheeses is shown in Table (3). The values of each fraction increased during ripening because of the proteolytic process. Proteolysis in cheese maturation plays an important role in the development of characteristics such as texture and flavor. McSweeney \& Sousa (2000) and Shenana \& Patel (2020).

Table 3 shows the amino acid profile of Taizzy soft cheese made with different types of probiotic bacteria when fresh and during storage period, there was an increase in free essential amino acids i.e. (histidine, lysine, leucine, isoleucine, methionine, valine, phenylalanine and threonine) and non-essential amino acids (Aspartic, Serine, Glutamic, Glycine, Alanine, Tyrosine, Arginine, Proline and Cysteine ) for all the cheese treatments either when fresh or during the interval storage up to 28 days due to the action of proteolytic either the enzymes or bacterial strains. The patterns of amino acids differ due to cheese verity, starter microorganisms, coagulation enzymes, type of coagulation and storage time. From the obtained date of amino acids of probiotic Taizzy soft cheese there was an increase of lysine and leucine essential amino acid of all the produced cheese same observatories were for Glutamic and Proline (non-essential) amino acids. These results agree with Shenana and Patel (2020).

\section{Rheological properties of probiotic Taizzy soft cheese \\ Penetrometer Reading \\ In the dairy industry the term "body" denotes the consistency of the product (e.g., firmness, softness, cohesiveness, and elasticity), whereas "texture" refers to the relative number, type and size of openings that can be observed visually or by the sense of touch to reveal internal particles (Lucey et al., 2003).}


TABLE 2. Ripening Indices of probiotic Taizzy cheese during storage at $5^{\circ} \mathrm{C}$

\begin{tabular}{|c|c|c|c|c|c|c|c|}
\hline Storage & $\mathrm{C} 1$ & $\mathrm{C} 2$ & T1 & $\mathbf{T 2}$ & T3 & T4 & MSE \\
\hline \multicolumn{8}{|c|}{ Soluble nitrogen (SN) \% } \\
\hline $\mathbf{0}$ & $0.21^{\mathrm{d}}$ & $0.21^{\mathrm{d}}$ & $0.24^{\mathrm{c}}$ & $0.25^{\mathrm{bc}}$ & $0.26^{\mathrm{b}}$ & $0.28^{\mathrm{a}}$ & 0.005 \\
\hline 7 & $0.24^{\mathrm{e}}$ & $0.26^{\mathrm{d}}$ & $0.28^{\mathrm{c}}$ & $0.36^{\mathrm{b}}$ & $0.36^{\mathrm{b}}$ & $0.40^{\mathrm{a}}$ & 0.005 \\
\hline 14 & $0.33^{\mathrm{e}}$ & $0.34^{\mathrm{e}}$ & $0.44^{\mathrm{d}}$ & $0.52^{\mathrm{c}}$ & $0.55^{\mathrm{b}}$ & $0.62^{\mathrm{a}}$ & 0.005 \\
\hline 21 & $0.42^{\mathrm{e}}$ & $0.42^{\mathrm{e}}$ & $0.54^{\mathrm{d}}$ & $0.58^{\mathrm{c}}$ & $0.60^{\mathrm{b}}$ & $0.65^{\mathrm{a}}$ & 0.005 \\
\hline 28 & $0.48^{\mathrm{f}}$ & $0.52^{\mathrm{e}}$ & $0.70^{\mathrm{d}}$ & $0.72^{\mathrm{c}}$ & $0.75^{\mathrm{b}}$ & $0.78^{\mathrm{a}}$ & 0.005 \\
\hline \multicolumn{8}{|c|}{ Soluble nitrogen /Total nitrogen (SN $/ \mathrm{TN}) \%$} \\
\hline 0 & $14.10^{\mathrm{d}}$ & $14.10^{\mathrm{d}}$ & $15.80^{\mathrm{bcd}}$ & $16.33^{\mathrm{abc}}$ & $16.88^{\mathrm{abc}}$ & $18.06^{\mathrm{a}}$ & 0.85 \\
\hline 7 & $15.28^{\mathrm{d}}$ & $16.60^{\mathrm{c}}$ & $15.23^{\mathrm{c}}$ & $22.64^{\mathrm{ab}}$ & $22.50^{\mathrm{b}}$ & $24.84^{\mathrm{a}}$ & 1.21 \\
\hline 14 & $20.37^{\mathrm{e}}$ & $20.61^{\mathrm{d}}$ & $26.19^{d}$ & $30.06^{\mathrm{c}}$ & $32.16^{\mathrm{b}}$ & $35.84^{\mathrm{a}}$ & 1.34 \\
\hline 21 & $22.82^{\mathrm{d}}$ & $22.58^{\mathrm{d}}$ & $30.56^{\mathrm{ab}}$ & $28.72^{\mathrm{c}}$ & $30.53^{\mathrm{ab}}$ & $31.25^{\mathrm{a}}$ & 2.36 \\
\hline 28 & $27.27^{\mathrm{d}}$ & $27.67^{\mathrm{cd}}$ & $36.84^{\mathrm{b}}$ & $37.31^{\mathrm{b}}$ & $38.66^{\mathrm{b}}$ & $40.44^{\mathrm{a}}$ & 2.42 \\
\hline \multicolumn{8}{|c|}{ Shilovich Ripening Index\% } \\
\hline $\mathbf{0}$ & $30.33^{\mathrm{c}}$ & $32.50^{\mathrm{b}}$ & $34.40^{\mathrm{a}}$ & $35.00^{\mathrm{a}}$ & $35.10^{\mathrm{a}}$ & $36.33^{\mathrm{a}}$ & 2.25 \\
\hline 7 & $36.58^{\mathrm{b}}$ & $36.61^{b}$ & $39.56^{\mathrm{a}}$ & $40.30^{\mathrm{a}}$ & $40.70^{\mathrm{a}}$ & $41.32^{\mathrm{a}}$ & 2.25 \\
\hline 14 & $44.22^{b}$ & $45.00^{\mathrm{b}}$ & $47.60^{\mathrm{a}}$ & $48.60^{\mathrm{a}}$ & $48.70^{\mathrm{a}}$ & $49.29^{\mathrm{a}}$ & 2.25 \\
\hline 21 & $52.50^{\mathrm{b}}$ & $52.80^{\mathrm{b}}$ & $54.00^{\mathrm{ab}}$ & $55.20^{\mathrm{a}}$ & $55.70^{\mathrm{a}}$ & $55.90^{\mathrm{a}}$ & 2.42 \\
\hline 28 & $61.33^{\mathrm{c}}$ & $61.37^{\mathrm{c}}$ & $63.53^{\mathrm{b}}$ & $65.60^{\mathrm{a}}$ & $66.00^{\mathrm{a}}$ & $66.43^{\mathrm{a}}$ & 2.42 \\
\hline \multicolumn{8}{|c|}{ Formol Ripening Index\% } \\
\hline $\mathbf{0}$ & $13.18^{c}$ & $13.65^{\mathrm{bc}}$ & $15.31^{\mathrm{ab}}$ & $16.64^{\mathrm{a}}$ & $15.54^{\mathrm{a}}$ & $16.51^{\mathrm{a}}$ & 0.85 \\
\hline 7 & $15.16^{\mathrm{b}}$ & $15.50^{\mathrm{b}}$ & $22.28^{\mathrm{a}}$ & 23.62 & 22.28 & 23.59 & 2.21 \\
\hline 14 & 25.25 & 25.85 & 30.30 & $32.24^{\mathrm{a}}$ & $30.37^{\mathrm{a}}$ & $33.07^{\mathrm{a}}$ & 2.23 \\
\hline 21 & $28.30^{c}$ & $29.29^{\mathrm{c}}$ & $36.31^{\mathrm{b}}$ & $38.38^{\mathrm{a}}$ & $36.52^{b}$ & $39.13^{a}$ & 2.52 \\
\hline 28 & $33.12^{\mathrm{d}}$ & $33.51^{\mathrm{d}}$ & $35.43^{\mathrm{c}}$ & $38.40^{\mathrm{c}}$ & $35.99^{\mathrm{b}}$ & $40.44^{\mathrm{a}}$ & 2.42 \\
\hline \multicolumn{8}{|c|}{ Soluble Tyrosine (mg/100mg) } \\
\hline 0 & $27.15^{b}$ & $27.17^{b}$ & $28.60^{\mathrm{ab}}$ & $29.13^{\mathrm{a}}$ & $29.16^{\mathrm{a}}$ & $30.00^{\mathrm{a}}$ & 1.68 \\
\hline 7 & $28.25^{\mathrm{d}}$ & $28.55^{\text {cd }}$ & $30.21^{\mathrm{bc}}$ & $31.12^{\mathrm{ab}}$ & $31.25^{\mathrm{ab}}$ & $32.54^{\mathrm{a}}$ & 1.68 \\
\hline 14 & $30.62^{\mathrm{b}}$ & $31.33^{\mathrm{b}}$ & $32.45^{\mathrm{ab}}$ & $33.85^{\mathrm{a}}$ & $34.00^{\mathrm{a}}$ & $34.10^{\mathrm{a}}$ & 1.68 \\
\hline 21 & $32.34^{\mathrm{b}}$ & $32.75^{\mathrm{b}}$ & $35.15^{\mathrm{a}}$ & $36.20^{\mathrm{a}}$ & $36.24^{\mathrm{a}}$ & $36.64^{\mathrm{a}}$ & 1.68 \\
\hline 28 & $33.18^{\mathrm{c}}$ & $33.50^{\mathrm{c}}$ & $36.16^{\mathrm{b}}$ & $38.25^{\mathrm{a}}$ & $38.30^{\mathrm{a}}$ & $39.12^{\mathrm{a}}$ & 1.68 \\
\hline \multicolumn{8}{|c|}{ Soluble Tryptophan (mg/100mg) } \\
\hline 0 & $9.09^{\circ}$ & $9.11^{\mathrm{b}}$ & $10.24^{\mathrm{ab}}$ & $11.23^{\mathrm{a}}$ & $11.30^{\mathrm{a}}$ & $11.52^{\mathrm{a}}$ & 0.62 \\
\hline 7 & $10.46^{\mathrm{a}}$ & $10.46^{\mathrm{a}}$ & $11.18^{\mathrm{a}}$ & 12.07 & 12.17 & 12.35 & 0.65 \\
\hline 14 & $11.56^{\mathrm{a}}$ & $12.12^{\mathrm{a}}$ & $13.21^{\mathrm{a}}$ & $13.66^{\mathrm{a}}$ & $13.72^{\mathrm{a}}$ & $14.03^{\mathrm{a}}$ & 0.67 \\
\hline 21 & $13.57^{\mathrm{b}}$ & $13.79^{\mathrm{ab}}$ & $14.17^{\mathrm{ab}}$ & $15.29^{\mathrm{sb}}$ & $14.23^{\mathrm{sb}}$ & $15.63^{\mathrm{s}}$ & 0.64 \\
\hline 28 & $15.18^{\mathrm{b}}$ & $15.39^{\mathrm{b}}$ & $16.42^{\mathrm{ab}}$ & $18.11^{\mathrm{a}}$ & $16.46^{\mathrm{ab}}$ & $18.22^{\mathrm{a}}$ & 0.63 \\
\hline \multicolumn{8}{|c|}{ TVFA (0.1N NaOH/100g of cheese) } \\
\hline $\mathbf{0}$ & $7.45^{6}$ & $7.62^{b}$ & $8.18^{5}$ & $8.91^{\mathrm{ab}}$ & $10.09^{\mathrm{a}}$ & $10.30^{\mathrm{a}}$ & 0.63 \\
\hline 7 & $12.25^{\mathrm{d}}$ & $13.59^{\mathrm{d}}$ & $20.51^{\mathrm{c}}$ & $22.00^{\mathrm{c}}$ & $26.14^{\mathrm{b}}$ & $28.17^{\mathrm{a}}$ & 1.11 \\
\hline 14 & $18.22^{\mathrm{c}}$ & $18.88^{\mathrm{c}}$ & $30.22^{b}$ & $31.85^{\mathrm{b}}$ & $34.21^{\mathrm{a}}$ & $35.10^{\mathrm{a}}$ & 1.21 \\
\hline 21 & $20.13^{d}$ & $20.92^{\mathrm{d}}$ & $38.07^{c}$ & $40.16^{\mathrm{b}}$ & $42.17^{\mathrm{a}}$ & $43.20^{\mathrm{a}}$ & 1.35 \\
\hline 28 & $24.15^{\mathrm{d}}$ & $24.71^{\mathrm{d}}$ & $52.10^{c}$ & $54.37^{\mathrm{b}}$ & $55.87^{\mathrm{b}}$ & $60.08^{\mathrm{a}}$ & 1.69 \\
\hline
\end{tabular}

(C1) Control without slurry (One hour), (C2) Control without slurry (two hours), (T1) L. rhamnosus Iso 7 (One hour), (T2) $L$. rhamnosus Iso 7(two hours), (T3) L. plantarum ATCC 14917 (One hour), (T4) L. plantarum ATCC 14917 (two hours), a,b,c Means with different superscript in the same row are significantly different at $(P<0.05)$. 
TABLE 3. Amino acids profile of Taizzy soft cheese made with different types of probiotic bacteria.

\begin{tabular}{|c|c|c|c|c|c|c|}
\hline \multirow{2}{*}{$\begin{array}{l}\text { Amino acid } \\
\text { Essential }\end{array}$} & \multicolumn{5}{|c|}{ Amino acids of cheese (\%) } & \multirow[b]{2}{*}{ T4 } \\
\hline & C1 & $\mathrm{C} 2$ & T1 & $\mathbf{T 2}$ & T3 & \\
\hline Histidine (HIS) & 0.32 & 0.30 & 0.20 & 0.28 & 0.32 & 0.30 \\
\hline Lysine (LYS) & 0.80 & 0.81 & 0.54 & 0.76 & 0.84 & 0.83 \\
\hline Leucine (LEU) & 1.03 & 0.95 & 0.60 & 0.86 & 0.93 & 0.95 \\
\hline Isoleucine (ILE) & 0.54 & 0.51 & 0.31 & 0.49 & 0.51 & 0.54 \\
\hline Methionine (met) & 0.35 & 0.33 & 0.20 & 0.29 & 0.38 & 0.29 \\
\hline Valine (VAL) & 0.63 & 0.58 & 0.37 & 0.54 & 0.62 & 0.58 \\
\hline Phenylalanine (PHE) & 0.55 & 0.49 & 0.33 & 0.51 & 0.55 & 0.54 \\
\hline Threonine (THR) & 0.48 & 0.45 & 0.28 & 0.40 & 0.48 & 0.45 \\
\hline \multicolumn{7}{|l|}{ Non-essential } \\
\hline Aspartic (ASP) & 0.82 & 0.73 & 0.44 & 0.68 & 0.74 & 0.76 \\
\hline Serine (SER) & 0.58 & 0.55 & 0.34 & 0.47 & 0.54 & 0.56 \\
\hline Glutamic (GLU) & 2.58 & 2.30 & 1.34 & 2.08 & 2.08 & 2.43 \\
\hline Glycine (GLY) & 0.20 & 0.20 & 0.11 & 0.18 & 0.19 & 0.20 \\
\hline Alanine (ALA) & 0.36 & 0.35 & 0.21 & 0.33 & 0.35 & 0.35 \\
\hline Tyrosine (TYR) & 0.53 & 0.22 & 0.10 & 0.43 & 0.05 & 0.30 \\
\hline Arginine (ARG) & 0.32 & 0.33 & 0.21 & 0.31 & 0.34 & 0.33 \\
\hline Proline (PRO) & 1.33 & 1.38 & 0.78 & 1.27 & 1.25 & 1.43 \\
\hline Cysteine (cys) & 0.20 & 0.17 & 0.08 & 0.21 & 0.17 & 0.17 \\
\hline
\end{tabular}

(C1) Control without slurry (One hour), (C2) Control without slurry (two hours), (T1) L. rhamnosus Iso 7 (One hour), (T2), L. rhamnosus Iso 7 (two hours), (T3) L. plantarum (One hour), (T4) L. plantarum (two hours).

Penetrometer reading is widely used for texture evaluation of food products. Human eating action normally consists of several bites. In order to better describe the eating actions of humans, analysis attributes i.e. (hardness, cohesiveness, gumminess, chewiness, adhesiveness and springiness) of resultant probiotic Taizzy soft cheese when fresh and during storage (28 days) at $5^{\circ} \mathrm{C}$ were shown in Fig. (2). Hardness can be defined as the force required reaching a given deformation or the maximum load from the compression max force attained during the first compression. All these parameters describe the product quality (soft, firm, hard) related to the cheese structure under compression of penetration. The results in Fig. 2 indicated that the hardness values were higher in all cheese treatments with added probiotic strains. The Penetrometer readings of probiotic Taizzy soft cheese during storage at $5^{\circ} \mathrm{C}$ period up to 28 days were recorded 61, 63, 66, 68, 67 and $69\left(0.1 \mathrm{~mm} / 10 \mathrm{sec}\right.$.) for $\mathrm{C}_{1}, \mathrm{C}_{2}, \mathrm{~T}_{1}, \mathrm{~T}_{2}, \mathrm{~T}_{3}$ and $\mathrm{T}_{4}$, for fresh cheese treatments respectively. These observations could be related to the ratio of T.S. which being the highest and influences cheese hardness. These results increased by storage progress to be $106,109,114,122,128$ and 134 for the same previous order. The obtained hardness results agreed with that of (Abd El-Aziz et al., 2012 \& Awad et al., 2012). The pH of cheese affects the texture of curd directly by influencing the solubility of the caseins, decreasing the $\mathrm{pH}$ of cheese, the penetration increased. Statistical analysis for the hardness (penetrometer reading) obtained data indicated that there were significant differences $(\mathrm{p} 0.05<)$ between the treatments according to the type of starter culture and by the storage periods.

Microbiological examinations of probiotic Taizzy soft cheese

Microbiological examinations of probiotic Taizzy soft cheese during storage period up to 28 days at $5^{\circ} \mathrm{C}$ are presented in Table 4 . The total bacterial counts (TBC) were gradually increased during cold storage and reach their maximum counts after 14 days of storage followed by slight decrease in all treatments up to the end of storage period ( 28 days). The decrease of TBC could be evidently attributed to the high acidity \& salt which control the rate of bacterial

Egypt. J. Food Sci. 48, No.2 (2020) 


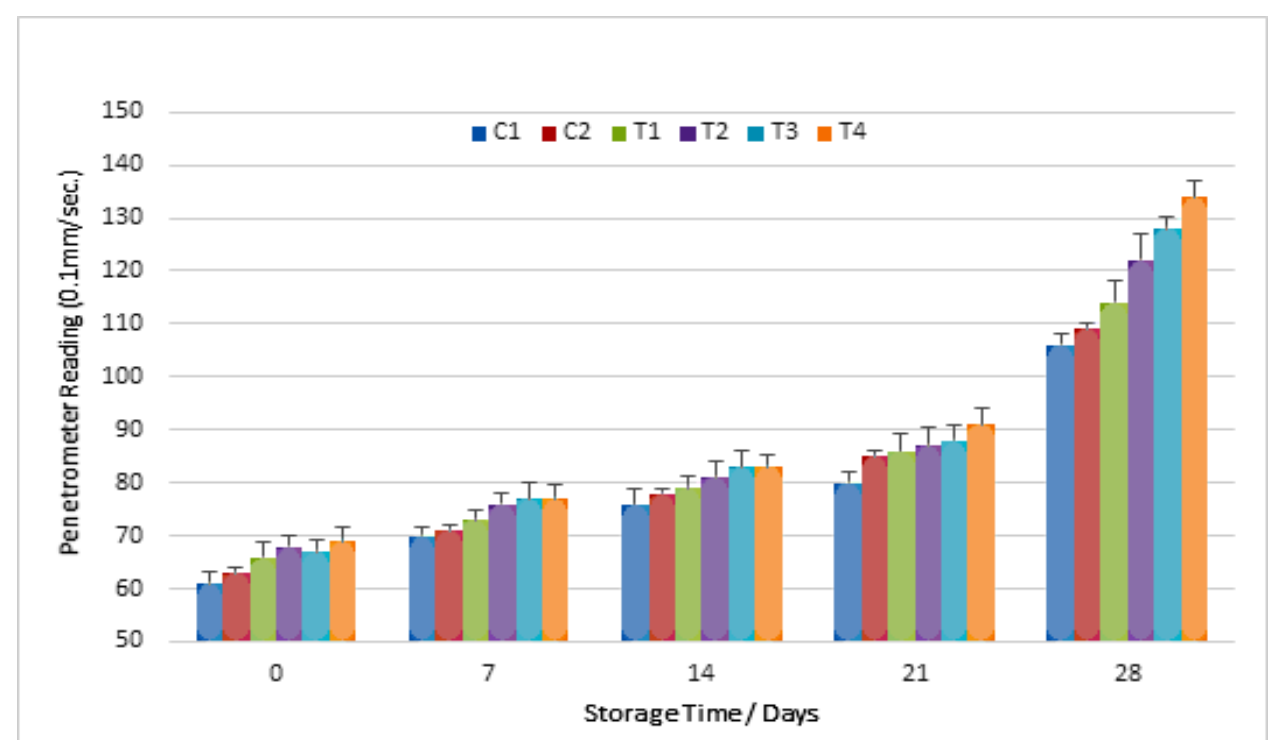

Fig. 2. Penetrometer Reading $(0.1 \mathrm{~mm} / 10 \mathrm{Sec}$.) of Taizzy soft cheese made with different types of probiotic bacteria during storage at $5^{\circ} \mathrm{C}$ up to 28 days. (C1) Control without slurry (One hour), (C2) Control without slurry (two hours), (T1) L. rhamnosus Iso 7 (One hour), (T2) L. rhamnosus Iso 7(two hours), (T3) L. plantarum ATCC 14917 (One hour), (T4) L. plantarum ATCC 14917 (two hours).

activity and low temperature which control the rate of bacterial growth and bactericidal agent. These results are in accordance with El-Alfy et al. (2010) and Songisepp et al. (2012). Generally, it can be found that probiotic Taizzy soft cheeses made with different probiotic strains had higher TBC compared to control $\left(\mathrm{C}_{1}\right)$, because it contains probiotic strains in addition to the starter culture. These findings are in harmony with the results obtained by Songisepp et al. (2012).

By the end of storage of probiotic Taizzy soft cheeses, there was a decrease of populations of Lactobacillus rhamnosus and Lactobacillus plantarum possibly caused by adverse conditions, such as low temperature and acid development along the storage periods. The results of probiotic bacterial counts indicated that these cheeses meet the requirements for probiotic functional cheese, as it have at least $10^{6} \mathrm{cfu} / \mathrm{g}$ or $6 \mathrm{log}$ $\mathrm{cfu} / \mathrm{g}$ of different probiotic strains even after storage periods (Tiwari et al., 2019). However, the addition of probiotic bacteria to probiotic Taizzy soft cheeses caused some enhancement in the numbers of all bacteria in a comparison to control cheese. The data showed that all Taizzy soft cheese made with different types of probiotic bacteria during storage contained the highest Lactobacilli count either when fresh or at the end of storage period. These results are in harmony with those obtained by Triana et al. (2016).
In general, cheeses show great advantages over other fermented dairy products like yoghurt as a vector for incorporating probiotic bacteria to diet because they have a higher $\mathrm{pH}$ and buffer capacity, higher consistency and more acceptability (Ong $\&$ Shah, 2009). These characteristics would be able to offer more protection to probiotic bacteria during storage and transit in the gastrointestinal tract (Gardiner et al., 1998). According to statistical analysis of microbiological examination for probiotic Taizzy cheese during storage periods there were non-significant differences for total bacterial count and Lactobacilli counts either between the treatments or storage periods.

The obtained data revealed that yeast and moulds were not detected in all produced probiotic Taizzy soft cheeses either when fresh or after storage at $\sim 5^{\circ} \mathrm{C}$ up to 28 days, this may be due to high quality of enriched probiotic Taizzy soft cheeses which related to the development of acidity and antibiotics production by starter cultures or probiotic bacteria during storage period and also, indicated that cheeses were produced and packaged in good hygienic practices. Moreover, after 28 storage days there were some yeast and moulds counts appeared in the produced probiotic Taizzy soft cheeses but less than $10 \mathrm{cfu} / \mathrm{g}$ which does not have any effect on the product acceptability. These results are in harmony with those obtained by Gouda (2006). 
TABLE 4. Microbiological examinations of probiotic Taizzy cheese during storage period up to 28 days at $5^{\circ} \mathrm{C}$

\begin{tabular}{|c|c|c|c|c|c|c|c|}
\hline $\begin{array}{c}\text { Storage } \\
\text { (days) }\end{array}$ & $\mathrm{C} 1$ & $\mathrm{C} 2$ & T1 & T2 & T3 & T4 & MSE \\
\hline \multicolumn{8}{|c|}{ Total Bacterial Count (log cfu/g) } \\
\hline $\mathbf{0}$ & $756^{a}$ & $7.64^{\mathrm{a}}$ & $8.19^{a}$ & $8.22^{\mathrm{a}}$ & $8.20^{a}$ & $8.24^{\mathrm{a}}$ & \multirow{6}{*}{$\begin{array}{l}0.98 \\
0.98 \\
0.98 \\
0.98 \\
0.98\end{array}$} \\
\hline 7 & & & & & & & \\
\hline 14 & $\begin{array}{l}7.65^{\mathrm{a}} \\
7.81 \mathrm{a}\end{array}$ & $\begin{array}{l}7.79^{\mathrm{a}} \\
782 \mathrm{a}\end{array}$ & $8.24^{\mathrm{a}}$ & $8.26^{\mathrm{a}}$ & $8.24^{\mathrm{a}}$ & $8.28^{\mathrm{a}}$ & \\
\hline 21 & $7.81^{\mathrm{a}}$ & $7.82^{\mathrm{a}}$ & $8.26^{\mathrm{a}}$ & $8.29^{\mathrm{a}}$ & $8.27^{\mathrm{a}}$ & $8.3 \mathrm{I}^{\mathrm{a}}$ & \\
\hline \multirow{2}{*}{28} & $7.62^{\mathrm{a}}$ & $7.73^{\mathrm{a}}$ & $8.21^{\mathrm{a}}$ & $8.25^{\mathrm{a}}$ & $8.23^{\mathrm{a}}$ & $8.27^{\mathrm{a}}$ & \\
\hline & $7.14^{\mathrm{a}}$ & $7.51^{\mathrm{a}}$ & $8.16^{\mathrm{a}}$ & $8.19^{\mathrm{a}}$ & $8.15^{\mathrm{a}}$ & $8.21^{\mathrm{a}}$ & \\
\hline \multicolumn{8}{|c|}{ Lactobacilli Count (log cfu/g) } \\
\hline $\mathbf{0}$ & $7.19^{\mathrm{a}}$ & $7.38^{\mathrm{a}}$ & $7.69^{\mathrm{a}}$ & $7.75^{\mathrm{a}}$ & $7.71^{\mathrm{a}}$ & $7.87^{\mathrm{a}}$ & 0.97 \\
\hline 7 & $7.36^{\mathrm{a}}$ & $7.56^{\mathrm{a}}$ & $7.82^{\mathrm{a}}$ & $7.89^{\mathrm{a}}$ & $7.85^{\mathrm{a}}$ & $7.97^{\mathrm{a}}$ & 0.97 \\
\hline 14 & $7.66^{\mathrm{a}}$ & $7.64^{\mathrm{a}}$ & $7.91^{\mathrm{a}}$ & $7.93^{\mathrm{a}}$ & $7.90^{\mathrm{a}}$ & $8.01^{\mathrm{a}}$ & 0.97 \\
\hline 21 & $7.33^{\mathrm{a}}$ & $7.50^{\mathrm{a}}$ & $7.79^{\mathrm{a}}$ & $7.88^{\mathrm{a}}$ & $7.84^{\mathrm{a}}$ & $7.93^{\mathrm{a}}$ & 0.97 \\
\hline 28 & $7.27^{\mathrm{a}}$ & $7.42^{\mathrm{a}}$ & $7.56^{\mathrm{a}}$ & $7.72^{\mathrm{a}}$ & $7.60^{\mathrm{a}}$ & $7.82^{\mathrm{a}}$ & 0.97 \\
\hline
\end{tabular}

(C1) Control without slurry (One hour), (C2) Control without slurry (two hours), (T1) L. rhamnosus Iso 7 (One hour), (T2) L. rhamnosus Iso 7(two hours), (T3) L. plantarum ATCC 14917 (One hour), (T4) L. plantarum ATCC 14917 (two hours), ${ }^{\mathrm{a}, \mathrm{b}, \mathrm{c}}$ Means with different superscript in the same row are significantly different at ( $\left.\mathrm{P} \square 0.05\right)$.

The detection of coliform groups in food products is very important as an indicator for quality and warning of health risk. From the coliform tests of produced probiotic Taizzy soft cheeses, they were not detected in all samples either when fresh or stored at $\sim 5^{\circ} \mathrm{C}$ up to 28 days and this may be due to the role of lactic acid bacteria (LAB) in preservation of the cheese which associated with their ability to produce a range of antimicrobial compounds, besides sufficient heat treatment of milk during processing, added salt and high sanitation conditions during making and storage of the products. These results are conformable with those of El-Alfy et al. (2010) and El-Kholy et al. (2016).

Sensory evaluation of probiotic Taizzy soft cheeses

The sensory evaluation indicated that time of the product during the refrigerated storage caused significant changes in acceptability. To produce healthy dairy products, it must be firstly organoleptically acceptable. Therefore, sensory evaluation of the cheese including flavour, body \& texture, appearance, and overall acceptability are illustrated in Fig. 3. Flavour means an overall integrated perception of taste and aroma associated with the product, which determine the acceptance or rejection of a food article. The flavour values of fresh samples significantly increased for all treatments and gained maximum at 14 days, ranging from 47 to 50 , for the control
$\left(\mathrm{C}_{1}\right)$ and treatment $(\mathrm{T} 3)$ made with L. plantarum ATCC14917, in the same order. The increase of flavor scores may be due to the development of aroma products by either starter cultures or probiotic strains while the reduction of off flavour was mainly related to the increase of acidity which masks aroma compounds perception by consumer. Treatments $\mathrm{T}_{1} \& \mathrm{~T}_{3}, \mathrm{~T}_{2} \& \mathrm{~T}_{4}$ recorded the highest scores while control recorded the lowest scorewhen fresh and throughout the interval storage period. These results agree with those obtained by Delavari et al. (2014), Ahmed et al. (2016) and Hammad (2019).

Concerning body \& texture of fresh cheese, the score ranged from 33.0 to 34.5 and then significantly increased by extending cold storage period to reach the maximum points after 28 days of storage period. The results of the panelists indicated that probiotic Taizzy soft cheeses treatments made with different probiotic strains achieved significantly higher scores of body\& textures than $\mathrm{C} 1$ when fresh and throughout the interval storage period. Similar results were obtained by Triana et al. (2016).

Appearance \&colour serves as a preliminary parameter for the acceptance of the product and indicates the fitness of the products for consumption. With respect to appearance \& colour (Fig. 3), there were very slight differences

Egypt. J. Food Sci. 48, No.2 (2020) 
in appearance \& colou $r$ scores among all fresh treatments ranged from 13 to 14 . Appearance \& color scores were significantly increased with the progress of storage period till the end of storage periods. Treatments with different probiotic strains improved appearance \&colour than the control. Similar trends werereported by Atallah (2013).

Overall acceptability is based on multiple organoleptic quality parameters i.e. flavor, color, texture, appearance, etc. and shows the accumulative perception and acceptance by the panelists. The overall acceptability of cheese was determined based on the average of the total score obtained for different sensory attributes. From the overall acceptability side of view for fresh treatments, the highest overall acceptabilities were recorded for the treatments $\mathrm{T}_{3}$ with score point 95.5 and $\mathrm{T}_{1}$ which scored (95 point), and the lowest acceptability score for the control $C_{1}$ (89 point).
Generally, the overall acceptability scores of samples significantly increased during cold storage up to the end. This could be associated with development of acidity and ripening indices. These findings are with the line of AbdRabouet al. (2016) and Triana et al. (2016).

Therefore, it could be reported that the sensory response to the probiotic Taizzy soft cheeses treatments made with different probiotic strains evidenced that the use of probiotic culture especially, Lactobacillus rhamnosus and Lactobacillus plantarum positively affected the overall sensory acceptability. There were significant differences for all sensory characteristics i.e. Flavour, Body \& Texture, Appearance and over all acceptability between different treatments and controls. Also, there were significant differences between the treatments during the storage periods.

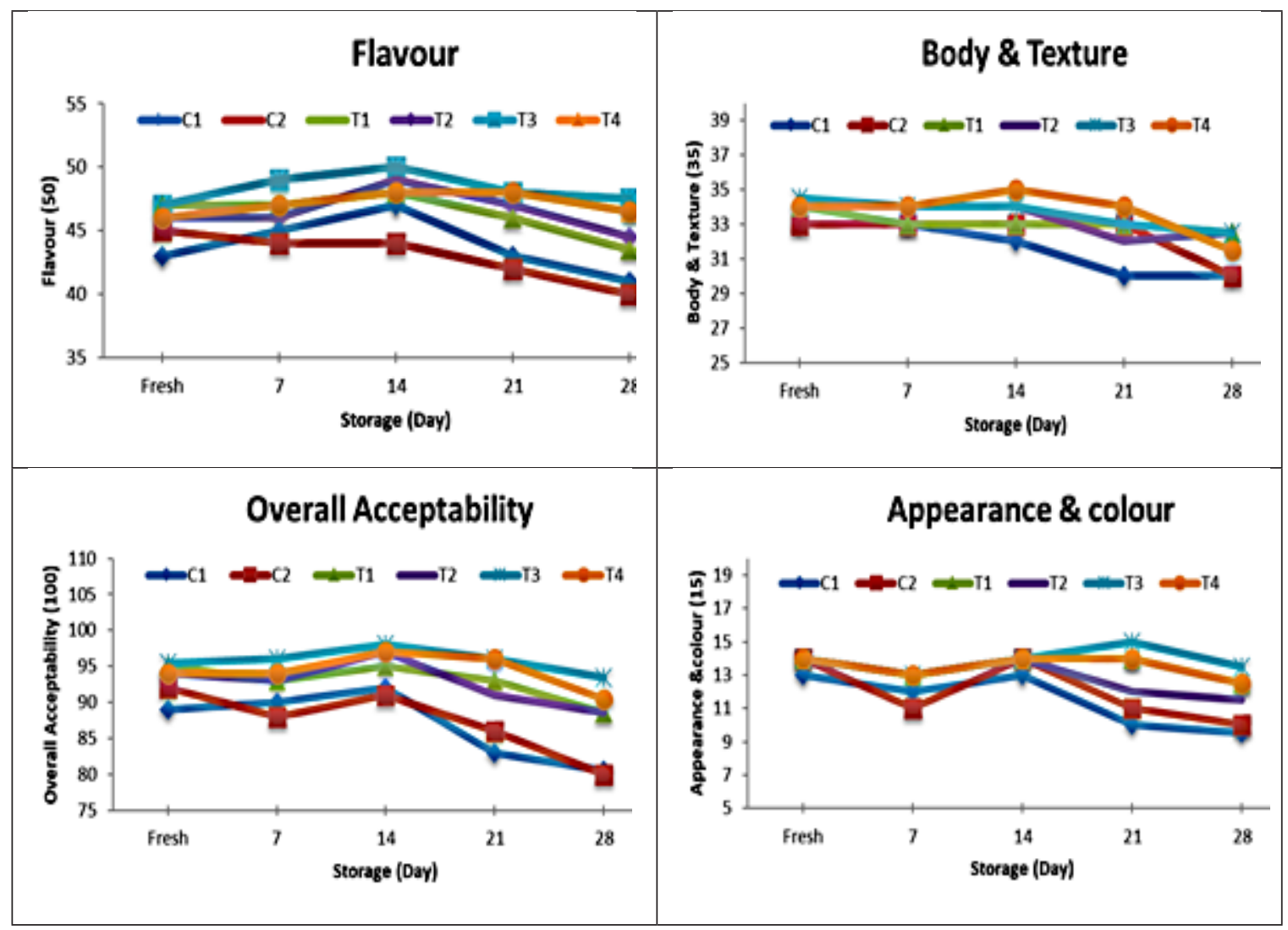

Fig. 3. Sensory evaluation scores of Taizzy soft cheese made with different types of probiotic bacteria during storage at $5^{\circ} \mathrm{C}$ up to 28 days. (C1) Control without slurry (One hour), (C2) Control without slurry (two hours), (T1) L. rhamnosus Iso7 (One hour), (T2) L. rhamnosus Iso7 (two hours), (T3) L. plantarum ATCC 14917 (One hour), (T4) L. plantarum ATCC 14917 (two hours). 


\section{Conclusion}

From such results it could be concluded that the probiotic Taizzy soft cheeses treatments can be made successfully using some probiotic culture (Lactobacillus rhamnosus, and Lactobacillus plantarum). The produced probiotic Taizzy soft cheeses made with different probiotic strains were in a good chemical, physical, rheological, microbiological, and sensory quality and the probiotic bacterial counts were more than $10^{6}$ $\mathrm{cfu} / \mathrm{g}$ which met the $\mathrm{FAO} / \mathrm{WHO}$ requirements for the probiotic products.

\section{References}

Abd-Elaty, M.A. (1994). Technological studies on smoked cheese. Ph.D. Thesis, Moshtohor, Zagazig Univ. Egypt.

Abd El-Aziz, M., Mohamed, S. H. S. and Seleet, F. L. (2012). Production and evaluation of soft cheese fortified with ginger extract as a functional dairy food. Pol. J. Food Nutr. Sci., 62, 77-83. https://doi. org/10.2478/v10222-011-0046-0

Abd-EL- Hamid L.B., Mahran G.A., Abbas H.A. and Hofei, A.A. (1991). Ample production condition for Ras cheese slurry. Egypt J. Dairy Sci, 9,327-335.

AbdRabou, H. S, El-Ziney, M., El-Sohaimy, S. A, Awad, S. (2016). Impact of Probiotic and Synbiotic Supplementation on the Physicochemical, Texture and Sensory Characteristics of Whey less DomiatiLike Cheese. MOJ Food process Technol., 3, 1-10. https://doi.org/10.15406/mojfpt.2016.03.00074

Abd El-Salam, B.A., Zayan, A.F. and Mailam, M.A. (2011). Effect of fortification with honey and Bifidobacterium strain on the characteristics of yoghurt. Egyptian J. Dairy Sci., 39, 65-74.

Abd El-Salam, M.H., Alichanidis, E. and Zerfiridis, G.K. (1993). Domiati and Feta Type Cheese. In: "Cheese: Chemistry, Physics and Microbiology", (Ed): Fox, P. F. Elsevier Applied Science, London, UK, PP. 301-335. https://link.springer.com/ chapter/10.1007/978-1-4615-2648-3 11

Abdulmalek M.A. and Abdulaziz A.A. (2011) Microbiological Changes and Determination of Some Chemical Characteristics for Local Yemeni Cheese. Jordan Journal of Biological Sciences, 4, 93 - 100. http://jjbs.hu.edu.jo/FILES/v4n2/ Paper\%20No.5\%20modified\%20.pdf

Ahmed, A.M.A., El-Demerdash, H.A., Shahein, M.R. and Metwally, M.M. (2016) Survival of some different probiotic strains in bio-yoghurt production. Ismailia J. Dairy Sci. \& Tech., Suez CanalUniv., 4, 1-7. https://dx.doi.org/10.21608/ ijds.2016.8072

Albenzio, M., Santillo, A., Caroprese, M., Ruggeri, D., Napolitano, F. and Sevi, A. (2013) Physicochemical properties of Scamorza ewe milk cheese manufactured with different probiotic cultures. Journal of Dairy Science, 96, 2781-2791. https:// doi.org/10.3168/jds.2012-6218

Algarni, E.H.A. (2016) Soft cheese supplemented with thyme, cumin, and turmeric to increase shelf life during storage period. Adv. Environm. Bio., 10, 227-236. http://www.aensiweb.net/AENSIWEB/ aeb/aeb/2016/December/227-236.pdf

Ali, A. R. M. (2010) Using of non-traditional methods for making soft cheese. MSc. Thesis, Fac. of Agric. Moshtohor, Benha Univ., Egypt.

APHA (2004) American Public Health Association. Standard methods for the examination of dairy products. American Publ. Health Assoc. Inc. 17 $7^{\text {th Ed. }}$, Washington D.C20001, USA.

AOAC, (2012). Official methods of Analysis of Association of Official Analytical Chemists $19^{\text {th }} \mathrm{ed}$., Published by AOAC International, Gaithersburg, Maryland 20877-2414, USA.

AOAC (2016) Official methods of Analysis of Association of Official Analytical Chemists. $20^{\text {th }}$ ed NO 994. 12-chapter 1 p. online Determination of Total Amino Acids

Astawan, M., Wresdiyati, T., Suliantari, S., Arief, I.I. and Septiawan, R. (2012). Production of synbiotic yoghurt-like using indigenous lactic acid bacteria as functional food. Media Peternakan, 35, 9-14. https://doi.org/10.5398/medpet.2012.35.1.9

Atallah, A.A. (2013). Technological aspects on functional dairy starter cultures. Ph.D. Thesis, Fac. Agric., Moshtohor, Benha Uni., Egypt.

Awad, R.A., Farahat, A.M. and Salama, W.M. (2012). Production and in vivo nutritional evaluation of functional soft cheese supplemented with broccoli. World J. Dairy \& Food Sci., 7, 150-159. http://www.idosi.org/wjdfs/wjdfs7(2)/6.pdf

BSI (1993) British Standards Institution. Determination of Enterobacteriaceae in microbiological examination of food and animal feeding stuffs. BSI 5763, British Standards Institution, London, U.K. 
BSI (1989) British Standards Institution. Chemical analysis of cheese. BSI, 770. British Standards Institution, London, U.K.

Dalloul S. M. (2000) Studies on smokes cheese. Ph. D. Thesis. Fac. Animal Production, Khartoum Univ. Republic of Soudan.

Delavari, M., Pourahmad, R. and Sokutifar, R. (2014) Production of low fat synbiotic yoghurt containing Lactobacillus Plantarum and inulin. Adv. Environ. Bio., 8, 17-24. http://www.aensiweb.com/old/aeb/ special $\% 205 \% 202014 / 17-24$.pdf

Dhankhar, J., Sharma, R., \&Indumathi, K. P. (2016) Bioactive lipids in milk. International Food Research Journal, 23, 2326-2334. http://www.ifrj. upm.edu.my/23\%20(06)\%202016/(3).pdf

Effat B. A.M., Mabrouk A. M.M., Sadek Z. I., Hussein G. A.M., and Magdoub M. N.I. (2012). Production of novel functional white soft cheese. Journal of Microbiology, Biotechnology and Food Sciences, 1, 1259-1278. https://www.jmbfs.org/wp-content/ uploads/2012/03/effat_jmbfs_0082.pdf

El-Alfy M. B., Shenana M. E, Ismail E. A., Gafour W. A. and Roshdy A. M. (2010) Improvement of non-traditional white soft cheese made from fresh milk fortified with adding skim milk powder and vegetable oils using different ratios of starter culture. Egypt. J. of Appl. Sci.,25, 495-518.

El-Kholy, W., Azzat B. Abd El-Khalek, S.H.S., Mohamed T. F.andJihan M. K. (2016). Tallaga Cheese as a New Functional Dairy Product. Am. J. Food Technol., 11, 182-192. http://dx.doi. org/10.3923/ajft.2016.182.192

El-Sayed. N.H., Abbas. H.M. and Ahmed. N.S (1993). Cheese slurry in the acceleration of Domiati cheese. Egyptian J. Dairy Sci.,21, 151- 162.

EL-Sayed, N.H and Abbas, H.M. (1992). Effect of milk on the properties of Ras cheese slurries. Egyptian J. Dairy Sci., 20, 371-380.

EL-Shafei, S. (2015). Technological study on Goats milk, Thesis Ph.D. Benha Univ., Egypt.

El-Shamery G.R. (2007). Microbiological studies on Taiz cheeses. Egypt. J. Appl. Sci., 22, 520-535.

Gamage, G.G.A.P., Adikari, A.M.J.B., Nayananjalie, W.A.D., Prasanna, P.H.P., Jayawardena, N.W.I.A. and Wathsala, R.H.G.R. (2016). Physicochemical, microbiological, and sensory properties of probiotic drinkable yoghurt developed with goat milk. Int. J. Scient. \& Res. Public., 6, 203-208. https://pdfs. semanticscholar.org/1170/633bcc0e1cbfa6747fce7 c527dcce81cc67f.pdf

Gardiner, G.E., Ross, R.P., Collins, J.K., Fitzgerald, G. and Stanton, G. (1998). Development of a probiotic cheddar cheese containing humanderived Lactobacillus paracasei strains. Applied Environmental Microbiology, 64, 2192-2199. https://www.ncbi.nlm.nih.gov/pmc/articles/ PMC106298/

Gomez M.J., Gaya P., Nuñez M., Medina M. (1996). Effect of Lactobacillus plantarum as adjunct starter on the flavour and texture of a semi-hard cheese made from pasteurised cows' milk. Lait, 76, 461472. https://doi.org/10.1051/lait:1996535

Gouda, M.A.M. (2006). Studies on Soft Cheese. M.Sc Thesis in Agric.Sci., Dairy Sci., El-Fayoum Univ., Egypt.

Hammad, M.N.A. (2019). Studies on producing some therapeutic dairy products. Ph.D. Thesis, Fac. Agric., Moshtohor, Benha Univ., Egypt.

Hofi, A.A., Hamid, L. A., Ahmed, N. S., \& Abbas, H. M. (1991). Acceleration of Ras cheese ripening by relevant slurry. Egyptian J. Dairy Sci., 19, 337-346.

IDF (1987) International Dairy Federation, Skimmed milk, whey, and butter milk. Determination of fat content. Rose gottieb Gravimetric Methods. IDF.22B

IDF (1997). International Dairy Federation. Sensory evaluation of dairy products by scoring reference method. Standard 99 C.

IDF (1996) International Dairy Federation. Milk. Determination of Fat Content.00ID.

Ismail, E. A. (2007). Characterization and genetic improvement of Lactobacilli for Application in Probiotic Dairy products Ph.D. Thesis, Kiel University, Kiel-Germany. https://nbn-resolving. org/urn:nbn:de:gbv:8-diss-26154

Karakus, M. and Alperden, I. (1995). Effect of starter composed of various species of lactic bacteria on quality and ripening of Turkish white pickled cheese. Lebensmittel-Wissenschaft und -Technologie, 28, 404-409. https://doi.org/10.1016/00236438(95)90024-1

Lucey, J.A., Johnson, M.E. and Horne, D.S. (2003). Invited review: Perspectives on the basis of the rheology and texture properties of cheese. J. Dairy Sci., 86, 2725-2743. https://doi.org/10.3168/jds. S0022-0302(03)73869-7

Egypt. J. Food Sci. 48, No.2 (2020) 
McSweeney P.L.H. and Sousa M.J. (2000). Biochemical pathways for the production of flavour compounds in cheeses during ripening: A review. Lait, 80, 293324. https://doi.org/10.1051/lait:2000127

Mehanna, N.M.Mousa, M. A. and Abd EL-Khair, A. A. (2008) Improvement of quality of Ras cheese made from pasteurized milk using special slurry from ewes' milk cheese. ArabUniv. J. Agric. Sci., Ain Shams Univ., Cairo, 16, 427-436. https://dx.doi. org/10.21608/ajs.2008.14980

Olga, S.P. and Nikos, G.C. (2016) Production of a Functional Fresh Cheese Enriched with the Probiotic Strain Lb. plantarum T571 Isolated from Traditional Greek Product. 1st International Multidisciplinary Conference on Nutraceuticals and Functional Foods Current Research in Nutrition and Food Science Vol. 4 (SI. 2), 169181. https://www.foodandnutritionjournal.org/ pdf/vol4noSpecialissue/Vol4_Conference Spl(1)_p_169-181.pdf

Ong, L. and Shah, N. (2009). Probiotic Cheddar cheese: Influence of ripening temperatures on survival of probiotic microorganisms. LWT - Food Science and Technology, 42, 1260-1268. http://dx.doi. org/10.1016/j.lwt.2009.01.011

Ong, L., Henriksson, A. and Shah N.P. (2007). Proteolytic pattern and organic acid profiles of probiotic Cheddar cheese as influenced by probiotic strains of Lactobacillus acidophilus, Lb. paracasei, Lb. casei or Bifidobacterium sp. International Dairy Journal, 17, 67-78. https://doi.org/10.1016/j. idairyj.2005.12.009

SAS Institute (1990). SAS User's Guide/STAT ver. 6.04 Fourth edition SAS Inst. Inc., Cary, NC., USA.
Shenana, M.E. and Patel, A.R. (2020) Starter Cultures: Classification, Traditional Production Technology, and Potential Role in Cheese Manufacturing Industries. Chapter 2 In: Microbiology for Food and Health Technological Developments and Advances. Editors: Deepak Kumar Verma and Ami R. Patel Prem Prakash Srivastav, PhD Balaram Mohapatra Alaa Kareem Niamah, PhD. Publisher: Apple Academic Press, $1^{\text {st }}$ edition.

Songisepp E., Hütt P., Rätsep M., Shkut E., Kõljalg S., Truusalu K., Stsepetova J., Smidt I., Kolk H., Zagura M., Mikelsaar M. (2012) Safety of a probiotic cheese containing Lactobacillus plantarumTensia according to a variety of health indices in different age groups. J. Dairy Sci., 10 ,5495-509. https://doi. org/10.3168/jds.2011-4756

Tiwari, P.K., Asgar, S., Uprit, S., Chauhan, M., Sandey, K.K. and Shinde, N.W. (2019) Effect of oat flour addition on the viability of drink. Int. J. Livestock Res., 9, 66-73. https://dx.doi.org/10.5455/ ijlr.20180430020654

Triana S., Winiati P.R., Nurheni S.P. (2016). Physicochemical and Stability of Goat Cheese with Mono and Mixed Culture of Lactobacillus plantarum and Lactobacillus rhamnosus. Animal Production. 18, 36-42. http://animalproduction.net/ index.php/JAP/article/view/533

Wijesundera C., Roberts M., and Limsowtin, G (1997). Flavour development in aseptic cheese curd slurries prepared with single-strain starter bacteria in the presence and absence of adjuncts. Le Lait, INRA Editions, 77, 121-131. https://hal.archivesouvertes.fr/hal-00929520 


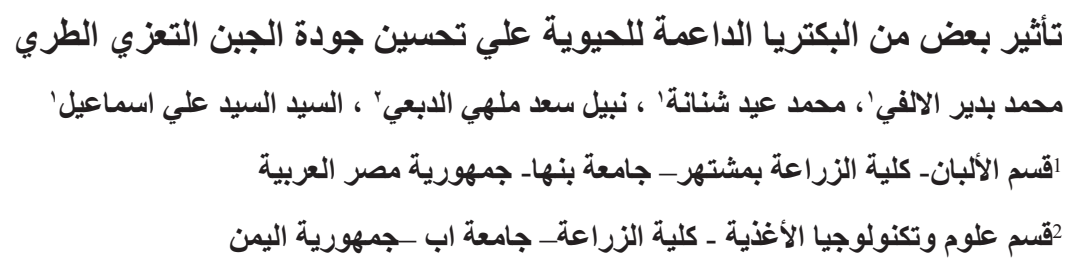

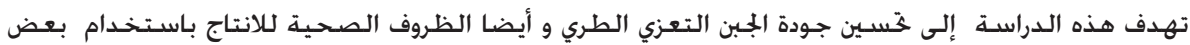

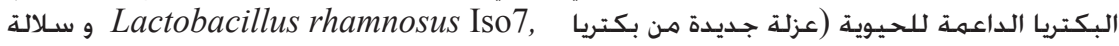

(Lactobacillus plantarum ATCC14917). وقـد تم دراسـة حيوية البكتريـا الداعمة للحيويـة المستخـدمة

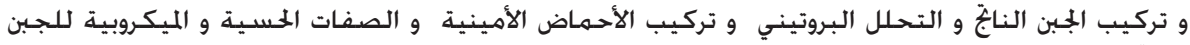

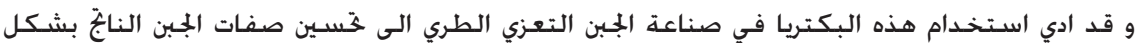

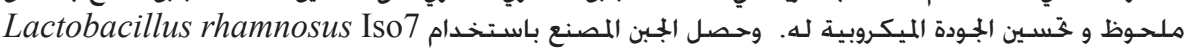

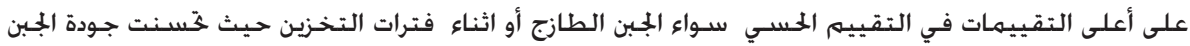

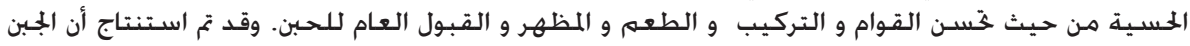

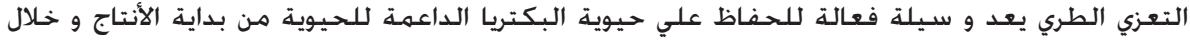

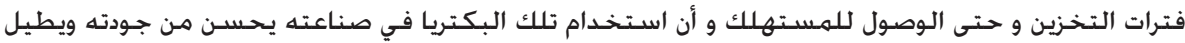

